\title{
ANALYSIS OF EDIBLE MUSHROOM MARKETING IN THREE VILLAGES IN CENTRAL CROSS RIVER STATE, NIGERIA
}

\author{
I. B. ADINYA, J. U. IJOMA, I. ENIL, G. EWONA, C. N ANYORAH AND N. E. OGAR
}

(Received 2 July 2012; Revision Accepted 28 July 2012)

\begin{abstract}
This study examined the marketing of edible mushroom in three villages (Alesi, Ekukunela and Ohon) in Central Cross River State, Nigeria. The marketing of edible mushroom in the state offers job opportunities for both skilled and unskilled rural population at farm gate and offers market employment opportunities for middlemen (wholesalers and retailers), enable talent utilization and stimulation of increase in edible mushroom production. The socio-economic characteristics of sellers, profit margin and marketing efficiency were the main focus. One hundred and twenty respondents were interviewed at three different markets in three selected villages in Central Cross River State, Nigeria, namely: Alesi, Ekukunela and Ochon. These markets were chosen because of the large number of edible mushroom sellers in them. However, the sellers were randomly selected. This study revealed that the marketing of edible mushroom in Central Cross River State was completely dominated by women and children, with

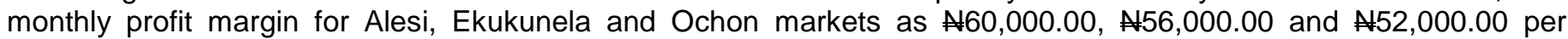
annual respectively. This suggests that edible mushroom marketing business was lucrative. The concentration of sellers is low while entry is free. The markets are thus prefect competitive markets. The regression analysis, however, revealed that of all the marketing costs, transportation had the most significant impact on the returns of sellers in all the studied markets. It was therefore recommended that farmers should form Mushroom Grower and Marketing Cooperative to enable them obtain loans from banks. Banks should provide loans with low interest rate to both small and large - scales genuine mushroom farmers and marketers (not politicians, motor park boys or civil servant). Furthermore, extension agents should monitor beneficiaries of such loans to ensure that the farmers or marketers do not divert funds to buy motor-cycles, cars or marry more wives and also they should ensure regular repayment of loans by loan beneficiaries. The study also recommended that government should implement action -research type of programs that integrate institutional-technical and socio-economic aspect of mushroom farming and include post harvest and marketing aspects either through cooperatives or export processing zones. Finally, the study recommended that serious attention should be paid to improve the markets to perfect markets for optimal efficiency.
\end{abstract}

KEY WORDS: Edible Mushroom, Nutrition, Improved Health, Marketing Efficiency

\section{INTRODUCTION}

Mushrooms belong to a group of living things called fungi. This group consists of heterogeneous organisms and includes moulds, mildews rusts, smuts, and toadstools. Their sizes vary from extremely tiny microscopic forms to large bracket fungi and there are also variations in structure and texture. Lacking in chlorophyll, they obtain directly already prepared organic material hence their prevalence on habitats such as forests (on trees, dead wood) and waste dump, where they cause disease, decay and destruction but also bring about changes which are beneficial to man and other organisms (Ramsbottom, 1977; Ekpo, 2001).
Fungi provide some basic nutritional and medicinal requirements for human beings. Investigations have shown that some mushrooms especially those belonging to the Order Agaricales are safe to eat while others are not. This has led to the categorization of mushrooms into edible and non-edible types. Hundreds of edible mushroom species abound in the world but most of them are not cultivated and less than ten species can be grown in large quantities (Ito, 1978; Ekpo, 2001). The edible mushroom species are often collected and eaten as useful supplements to diets (Ekpo, 2001). In Europe, North America, Japan, China, South East Asia and Australia where adequate

I. B. Adinya, Department of Agricultural Economics and Extension, Cross River University of Technology, Obubra Campus, Cross River State, Nigeria

J. U. Ijoma, Department of Forestry and Wild Life, Cross River University of Technology, Obubra Campus, Cross River State, Nigeria

I. Enil, Department of Agric Education, Cross River University of Technology, Obubra Campus, Cross River State, Nigeria

G. Ewona, Department of Agric Education, Cross River University of Technology, Obubra Campus, Cross River State, Nigeria

C. N. Anyorah, Department of Forestry and Wild Life Management, Federal University of Technology, Owerri, Nigeria.

N. E. Ogar, Department of Forestry and Wild Life, Cross River University of Technology, Obubra Campus, Cross River State, Nigeria 
technology is available, they are cultivated for export trade and local consumption. A few species are eaten for their hallucinogenic effects (Nicholson, 1989).

In Nigeria, over the years, several edible mushrooms have been identified in various communities. These have been found growing in several habitats including grass-land, forest floor, near termite hills, on dead and living trees, and in various waste dumps such as sawdust. They form part of the nonwood forest resources (Ekpo, 2001).

The people of Cross River State and indeed most people in Nigeria use edible mushroom for food and medicine. They are eaten mainly for their palatability.

Mushrooms are now known to be a good source of protein, minerals and vitamins and are also said to contain other health promoting substances and they are prized as delicacy for more than 2000 years now (Quimio et al., 1990). The earliest and first comprehensive accounts of mushrooms cultivation in France was given by Tournefort (1707) and Ekpo, (2001).

According to (Quimio et al., 1990) horse manure was used to sow spores from wild mushrooms in Holland, Italy, China and some Western European countries. With the establishment of laboratories for research on mushroom growing in these countries, improved technologies on use of mushroom growing houses and pure culture spawn have led to increased and rapid production of mushrooms worldwide. Today, China is major producer of mushrooms in the world (Oei, 1996).

In Nigeria, and indeed Cross River State, human population has continued to grow at a rate much faster than the rate of food production. Meanwhile, the down turn in our national economy has resulted in wide spread poverty and low purchasing power of the citizenry. The recent ban on the importation of livestock products has further put the cost of animal protein beyond the reach of many, especially the rural population.

The above scenarios have combined to keep the diets of the average Nigerians low in protein content and deficient in most essential minerals and vitamins (Akpet et al, 2005). The nutritional status of the people of Cross River State has been increased, through consumption of mushrooms that are now known to be a good source of protein, minerals, vitamins and are also said to contain other health promoting substances.

Mushrooms have the economic advantage over other crop plants in their ability to grow on waste agricultural products like sawdust, straws, sugar-cane waste products and coconut waste products. With such materials being readily available in the Nigerian environment, knowledge of simple and low cost techniques of mushroom cultivation could create a source of income and improved nutritional base for the poor and rich. Mass production and subsequent export of such cultivated mushrooms could also be a source of foreign exchange earning.

Although several studies have been conducted on mushroom cultivation and storage, but none concerns the marketing of edible mushrooms.

Mushrooms are highly rated for being rich in protein, vitamins and minerals. They are said to be low in calories and cholesterol content. For instance, mushroom contains about 94\% moisture, 3-4\% protein on fresh basis, but about $35 \%$ on dry basis; an average of $4 \%$ fat and unsaturated fatty acids, mainly linoleic acid constitute about $72 \%$. It is also high in thiamin (B1), Riboflavin (B2), Niacin and ascorbic acid (Crisan and Sands, 1978). Some varieties are medicinal and known for providing stamina and resistance to disease. It is also used for treating of diabetes (Ekpo, 2001). Others serve as dyes for fabrics as well as to bio-remediate polluted soils or neutralize acidic soils (Grey, 1970).

Edible mushroom' principal nutritional function is the supply of protein, vitamins and minerals to the body. In Nigeria, many tribes are known to use different mushrooms and in some cases it is very important to use a particular mushroom in local festivals. For instance, the use of pleurotus tuber require in the preparation of paddy that is always offered visitors during the Owu festival in Imo state (Kennedy, 2004).

Mushrooms have been treated as a special kind of food since earliest times. Chinese and Japanese chronicles, indicate that the shutake mushroom was collected from the wild and given to the Emperors as a tribute. The Roman's ate mushrooms on special occasions. In some cultures, however, all mushrooms are considered toadstool poisonous gifts from the Devil. Nowadays, migration of millions of people with different food habits has spread the popularity of mushrooms. People are now aware that mushrooms are highly priced because of their taste, protein, vitamins, minerals and medicinal content. Mushroom soup is prepared with meat, fish or green vegetable. It plays an important role in social and religious festivals. In fact in mushroomgrowing areas of Nigeria, mushroom is vital and an integral part of their cultural heritage. It also occupies a place in many traditional marriage ceremonies and in special diets for fetish priests in sacrificial ceremonies (Kennedy, 2004; Ogbonnaya, 2006).

\section{Theoretical Framework/Literature Review}

Agricultural marketing is important in the sense that it acts as a link between production and consumption. In order that agricultural marketing fulfill this obligation, there are different services which have to be undertaken before agricultural produce can reach the consumers. Different levels of costs are incurred in rendering these services along the marketing channels and the total cost determines what the last consumer pays for a given quantity of farm product.

Marketing assumes greater importance in the Nigerian economy because the excess production from farm must be disposed off so that producers can earn income necessary for the purchase of other goods and services they do not produce. Furthermore, agricultural marketing is an indicator of consumers' preferences through the prices they are willing to pay. This affects the production decision of farmers as they are likely to produce crops, which have high demand and consequently higher returns. It is therefore, factual that efficient marketing is one of the greatest stimulants of the national economy in its efficient state.

Kohl's and Uhl (1980) defined marketing as all the intermediate steps from primary production involved in the flow of goods and services from the point of initial production until they reach the ultimate consumers. 


\section{METHODOLOGY}

STUDY AREA: The research study was carried out in Central Cross River State. The state occupies an area of about 22,342.176 square kilometers (Quarterly Newsletter of the Ministry of Local Government Affairs, Cross River State 2006). It is located at latitude $5^{\circ} 25^{\prime} \mathrm{N}$ and longitude $25^{\circ} 00^{\prime} \mathrm{E}$. The soil is utisol and alifisol(but predominantly utisol) (USDA) or Fluvisol (FAO/UNESCO, 1974).Cross River State has the largest rainforest covering about 7,290 square kilometers described as one of Africa's largest remaining virgin forest harbouring as many as five million species of animals, insects and plants(MOFINEWS, 2004).It is located within the evergreen rainforest zone. There are two distinct climatic seasons in the area namely rainy season from March to October and dry season from November to February. The annual rainfall varies from $2,942 \mathrm{~mm}$ to $3,424 \mathrm{~mm}$. The average temperature is around 28 degree Centigrade (CRADP,1992).About 8 million people inhabit the area,of which the Efiks, Ejaghams and Bekwarras are the major ethnic groups.

\section{STUDY POPULATION AND SAMPLE SIZE} A sample of 120 edible mushroom sellers (marketers) was randomly (multistage random sampling) selected for the study. This served as the population for the study. The first stage involved selection of three villages in Central Cross River State. This was followed by a random selection of three markets in the local government areas. The respondents were randomly selected from each of the markets. 40 respondents were selected each from Alesi, Ekukunela and Ochon markets, making a total number of 120 edible mushroom sellers. Some species of edible mushrooms that were sold in the markets that are used for food and medicine include the following: Auricularies pshytrica popularly called mouse ear mushroom, Chlorophyllum molybdites (Mayer ex Fr.) Massee, Coprinus lagopus (Fr.) Fries, Lentinus saja - Caju, Lentinus squaaosulums Popularly called Okokobioko, Lentinus squarrosulus (Pleurotus squarosulus) (Mont.) singer, Lentinus tuber-regium (pleurotus tuber regium) popularly called Omori oyster mushroom and locally called Isuor (Efik), Usu (Igbos) lquiya (Bekwarra), Pleurotus escolerthus, Volvariella volvacea (Bullex Fr.) Singer, Schizophyllum commune Fries, Termitomyces mammiformis Heim, Termitomyces clypeatus (Heim) and Termitomyces robustus (Beeli) Heim (Ogbonnaya, 2006),

\section{DATA COLLECTION AND ANALYSIS}

The instrument used for data collection was modified enterprise level interview guide that contained structured and semi-structured questions. The researchers interviewed each respondent personally. Data obtained from the study were analyzed using descriptive statistic and quantitative statistics. The descriptive statistics include tables, means, frequencies and budgetary analysis.

The quantitative statistics is the regression analysis. Regression analysis is important and useful for describing the relationship between the exogenous and endogenous variables. It estimates the statistical significance of the exogenous variables as well as the overall effect of all these variables on the endogenous variable. The general form of regression model for this analysis is given by:

$Y=f\left(X_{1}, X_{2}, X_{3}, X_{4}, X_{5}, X_{6}, X_{7}, X_{8}, X_{9}, X_{10} e_{1}\right)$

where $Y=$ Average monthly sales of edible mushroom marketers (naira)

$\mathrm{X}_{1}, \quad=$ Sex of the respondent

$\mathrm{X}_{2}, \quad=$ Educational level of the respondent

$\mathrm{X}_{3}, \quad=$ Marital Status of the respondent

$\mathrm{X}_{4}, \quad=$ Age of the respondent (years)

$\mathrm{X}_{5}, \quad=$ income of respondent (naira)

$\mathrm{X}_{6}, \quad=$ Price of mushroom (naria)

$\mathrm{X}_{7}, \quad=$ Taxes (naira)

$\mathrm{X}_{8}, \quad=$ Quantity of edible mushroom consumed monthly $(\mathrm{kg})$

$\mathrm{X}_{9}, \quad=$ Average cost of transportation per month(naira)

$\mathrm{X}_{10}, \quad=$ Experience in (years)

$\mathrm{e}_{1} \quad=$ Error term

four linear function forms were fitted in the analysis, these are Linear, Double logarithm, Exponential and semi-log function forms.

\section{FINDINGS AND DISCUSSION}

Table 1: Sex Distribution of Respondents (Sellers)

\begin{tabular}{|c|c|c|c|c|c|c|c|c|}
\hline & \multicolumn{7}{|c|}{ Number of Respondents and Overall Percentage } & \multirow{3}{*}{$\begin{array}{l}\text { Total } \\
\text { Number }\end{array}$} \\
\hline S/No & Gender & \multicolumn{2}{|c|}{ Alesi } & \multicolumn{2}{|c|}{ Ekukunela } & \multicolumn{2}{|l|}{ Ochon } & \\
\hline & & Number & $\%$ & Number & $\%$ & Number & $\%$ & \\
\hline 1. & Male & 7 & 17.5 & 5 & 12.5 & 9 & 22.5 & 21 \\
\hline 2. & Female & 33 & 82.5 & 35 & 87.5 & 31 & 77.5 & 99 \\
\hline & Total & 40 & 100 & 40 & 100 & 40 & 100 & 120 \\
\hline
\end{tabular}

Source: Field survey, 2011. 
Table 1 indicates that the bulk of edible mushroom sellers were women in each market $(82.5$ percent, 87.5 percent and 77.5 percent in Alesi, Ekukunela and Ochon market respectively. Female sellers (82.5\%) were more than male sellers (17.5\%) engaged in marketing of edible mushrooms.

Table 2: Distribution of Respondents According to Educational Attainment/Qualification.

\begin{tabular}{|l|l|l|l|l|}
\hline Educational Attainment & Alesi & Ekukunela & Ochon & $\begin{array}{l}\text { Total } \\
\text { Distribution }\end{array}$ \\
\hline OND/HND/B.sc/M.sc/Ph.D & 2 & 1 & 0 & 3 \\
\hline $\begin{array}{l}\text { Junior Secondary } \\
\text { certificate Senior } \\
\text { Secondary Certificate }\end{array}$ & 4 & 2 & 9 & 15 \\
\hline FSLC & 10 & 8 & 7 & 20 \\
\hline No education & 19 & 12 & 9 & 31 \\
\hline Total & 40 & 17 & 15 & 51 \\
\hline
\end{tabular}

Source: Field survey, 2011.

Table 2 reveals that 25.83 percent of the respondents had First School Leaving Certificate (FSLC), 16.67 percent attended Senior Secondary School. $2.5 \%$ of them attended high education. Only $42.5 \%$ of them did not had any form of education.

Table 3: Marital Distribution of Respondents (Sellers)

\begin{tabular}{|l|l|l|l|l|}
\hline & \multicolumn{4}{|l|}{ Number of Respondents and Overall percentage } \\
\hline Marital status & Alesi & Ekukunela & Ochon & Total number \\
\hline Married & 15 & 12 & 18 & 45 \\
\hline Widowed & 5 & 6 & 10 & 21 \\
\hline Single & 20 & 22 & 12 & 54 \\
\hline Total & 40 & 40 & 40 & 120 \\
\hline
\end{tabular}

Source: Field survey, 2011.

Analysis presented in table 3 reveals that $37.5 \%$ of the respondents are married, $17.5 \%$ are widowed. Only $45 \%$ of the respondents are single.

Table 4: Age Distribution of Sellers (Respondents)

\begin{tabular}{|l|l|l|l|l|}
\hline Age Group & Alesi & Ekukunela & Ochon & Total Distribution \\
\hline $21-30$ & 9 & 6 & 5 & 20 \\
\hline $31-40$ & 13 & 15 & 12 & 40 \\
\hline $41-50$ & 11 & 13 & 15 & 39 \\
\hline $51-$ above & 7 & 6 & 8 & 21 \\
\hline Total & 40 & 40 & 40 & 120 \\
\hline
\end{tabular}

Source: Field Survey, 2011

Table 4 revealed that edible mushroom sellers were mainly adults from above 21 years, however, $79 \%$ of them were aged between 31 and 51 years. Only $20 \%$ of the were between $21-30$ years and $21 \%$ of them between 51 years and above.

Table 5: Distribution of Respondents According to sources of Capital

\begin{tabular}{|l|l|l|l|l|}
\hline Source of Capital & Alesi & Ekukunela & Ochon & $\begin{array}{l}\text { Total } \\
\text { Distribution }\end{array}$ \\
\hline Friends/relatives & 9 & 10 & 7 & 26 \\
\hline Personal savings & 20 & 15 & 12 & 47 \\
\hline Inheritance & 6 & 5 & 8 & 19 \\
\hline Cooperative & 2 & 4 & 5 & 11 \\
\hline Loan from bank & 3 & 6 & 8 & 17 \\
\hline Total & 40 & 40 & 40 & 120 \\
\hline
\end{tabular}

Source: field survey, 2011. 
Table 5 indicate that sellers financed this business through personal savings $(39.17 \%)$, borrowing from friends or relatives(21.67\%), inheritance(15.83\%), cooperative and loan from bank being $9.17 \%$ and $14.16 \%$ respectively.

Table 6: Average Monthly Cost Analysis for edible mushroom Marketing in Central Cross River State.

\begin{tabular}{|l|l|l|l|}
\hline Function Cost & Alesi & Ekukunela & Ochon \\
\hline Purchase cost & $98,682.35$ & $80,403.65$ & $75,785.25$ \\
\hline Transport & $11,500.30$ & $10,300.20$ & $9,500.50$ \\
\hline Expenditure on rent/ticket & $1,250.20$ & $1,150.50$ & 1200.20 \\
\hline Cost of assembling/haulage & 400.50 & 380.60 & 370.20 \\
\hline Association levies & 250.00 & 250.00 & 250.00 \\
\hline Others (feeding) & 350.00 & 280.00 & 300.00 \\
\hline Total & $112,433.35$ & $92,764.95$ & $87,406.15$ \\
\hline
\end{tabular}

Source: Computed from field survey, 2011.

Footnote: the unit cost of edible mushroom was N300.00 per kilogram and the time frame: January - December, 2011 Table 6 revealed that Alesi marketers had the highest cost as a result of the quantity of edible mushrooms (N112,433.35 per month) they bought at the farm gate price. More buyers go to Alesi market than Ekukunela and Ochon markets, so sellers in Alesi market supply more edible mushrooms to meet up with the demand for edible mushrooms in the market.

Table 7: Average Profit margin Analysis for edible mushroom Marketing in Central Cross River State ( $\mathrm{N}$ 60,000.00, $\mathrm{N}$ $56,000.00$ and $N 52,000.00$ per month the unit cost of edible mushroom was $N 300.00$ per kilogram and the time frame was January - December, 2011)

\begin{tabular}{|l|l|l|l|}
\hline Item & Alesi & Ekukunela & Ochon \\
\hline Sales(Average Total Revenue)(ATR) & $172,433.35$ & $148,764.95$ & $139,406.15$ \\
\hline Purchases & $98,682.35$ & $80,403.65$ & $75,785.25$ \\
\hline Transport cost & $11,500.30$ & $10,300.20$ & $9,500.50$ \\
\hline Expenditure on rent & 1250.20 & 1150.50 & 1200.20 \\
\hline Cost of assembling/haulage & 400.50 & 380.60 & 370.20 \\
\hline Association levies & 250.00 & 250.00 & 250.00 \\
\hline Others & 350.00 & 280.00 & 300.00 \\
\hline Average Total Cost(ATC) & $112,433.35$ & $92,764.95$ & $87,406.15$ \\
\hline Profit margin & $60,000.00$ & $56,000.00$ & $52,000.00$ \\
\hline
\end{tabular}

Source: Computed from field survey, 2011.

Table 7 revealed that Alesi marketers made profit margin of $A 6,000.00$ per month; the unit cost of edible mushroom was N300.00 per kilogram and the time frame was January - December, 2011, while Ekukunela and Ochon make profit margin of $\mathrm{N} 56,000.00$ and $\mathrm{N} 52,000.00$ respectively.

Table 8: Evaluation of efficiency of edible mushroom marketing function performance

\begin{tabular}{|l|l|l|l|}
\hline Evaluation of efficiency & Alesi & Ekukunela & Ochon \\
\hline Average total cost (ATC) & $112,433.35$ & $92,764.95$ & $87,406.15$ \\
\hline Average total revenue (ATR) & $172,433.35$ & $148,764.95$ & $139,406.15$ \\
\hline Pricing Efficiency ATR & 1.53 & 1.60 & 1.59 \\
\hline
\end{tabular}

Source: Computed from field survey, 2011.

Table 8 revealed that all the surveyed markets were found to be efficient because their pricing efficiency ratio was greater than 1. This implies that the edible mushroom sellers were producing expected marketing function at the least possible cost. Therefore, it may be concluded that they were satisfying consumers in all the markets. 
Table 9: Revenue Analysis for edible mushroom marketing

\begin{tabular}{|l|l|l|l|}
\hline Revenue Item & Alesi & Ekukunela & Ochon \\
\hline Sale Revenue & $172,433.35$ & $148,764.95$ & 139406.15 \\
\hline Home consumption & 500.20 & 450.00 & 600.50 \\
\hline Total & $172,933.55$ & $149,214.95$ & $140,006.65$ \\
\hline
\end{tabular}

Source: Computed from field survey, 2011.

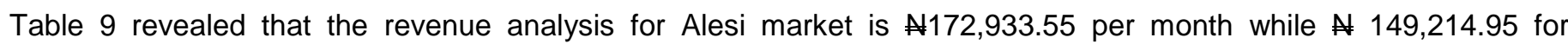
Ekukunela market and N 140,006.65 for Ochon market.

Table 10: Nutritional value of $1 \mathrm{~kg}$ of edible mushroom

\begin{tabular}{|l|l|}
\hline Constituent & Composition \\
\hline Calories & Low joules \\
\hline Protein on fresh basis & $3-4 \%$ \\
\hline Protein on dry basis & $35 \%$ \\
\hline Fat & $4 \%$ \\
\hline Vitamin & Traces \\
\hline Thiamine & High \\
\hline Riboflavin & High \\
\hline Niacin acid & High \\
\hline Ascorbic acid & High \\
\hline
\end{tabular}

Source: Adapted from Crisan and Sands, 1978.

Table 11: Result of Regression Analysis

\begin{tabular}{|c|c|c|c|c|c|c|c|c|c|c|c|c|}
\hline $\begin{array}{l}\text { LOCATI } \\
\text { ON }\end{array}$ & $\begin{array}{l}\text { CONS } \\
\text { TANT }\end{array}$ & $\begin{array}{l}X_{1} \\
\text { Sex }\end{array}$ & $\begin{array}{l}\mathrm{X}_{2} \\
\text { Edu. } \\
\text { Level }\end{array}$ & $\begin{array}{l}X_{3} \\
\text { Marital } \\
\text { Status }\end{array}$ & $\begin{array}{l}\mathrm{X}_{4} \\
\text { Age }\end{array}$ & $\begin{array}{l}X_{5} \\
\text { Inco } \\
\text { me }\end{array}$ & $\begin{array}{l}X_{6} \\
\text { Price }\end{array}$ & $\begin{array}{l}\text { Taxe } \\
\text { sX }_{7}\end{array}$ & $\begin{array}{l}\mathrm{X}_{8} \\
\text { Cons } \\
\mathrm{u}- \\
\mathrm{mptio} \\
\mathrm{n}\end{array}$ & $\begin{array}{l}X_{9} \\
\text { Tran } \\
\\
\text { port }\end{array}$ & $\begin{array}{l}\mathrm{X}_{10} \\
\text { Expe- } \\
\text { nces }\end{array}$ & $\begin{array}{l}\mathrm{R} \\
2\end{array}$ \\
\hline Alesi & $\begin{array}{l}316062 \\
(1.580)\end{array}$ & $\begin{array}{l}50.94 \\
0^{* *} \\
(1.4)\end{array}$ & $\begin{array}{l}102057^{*} \\
(0.49)\end{array}$ & $\begin{array}{l}-555298^{*} \\
(2.7)\end{array}$ & $\begin{array}{l}4901 \\
6^{*} \\
(3.1)\end{array}$ & $\begin{array}{l}5057 \\
9^{* *} \\
(2.9)\end{array}$ & $\begin{array}{l}2763 \\
0 \\
(0.29 \\
)\end{array}$ & $\begin{array}{l}6095 \\
4 \\
(-0.9)\end{array}$ & $\begin{array}{l}-244^{*} \\
(-3.1)\end{array}$ & $\begin{array}{l}-223^{*} \\
(-3.1)\end{array}$ & $\begin{array}{l}22850 \\
* \\
(2001 \\
)\end{array}$ & $\begin{array}{l}0.67 \\
4\end{array}$ \\
\hline $\begin{array}{l}\text { Ekukune } \\
\text { la }\end{array}$ & $\begin{array}{l}383434 \\
(1.4)\end{array}$ & $\begin{array}{l}1232 \\
87^{\star *} \\
(1.8)\end{array}$ & $\begin{array}{l}998899^{*} \\
(3.0)\end{array}$ & $\begin{array}{l}-59257^{*} \\
(-1.5)\end{array}$ & $\begin{array}{l}1182 \\
55^{*} \\
(3.7)\end{array}$ & $\begin{array}{l}- \\
6814 \\
53^{\star *} \\
(-2.0)\end{array}$ & $\begin{array}{l}2795 \\
8 \\
(0.90 \\
)\end{array}$ & $\begin{array}{l}- \\
9242 \\
2 \\
(-1.1)\end{array}$ & $\begin{array}{l} \\
2064 \\
(-2.2)\end{array}$ & $\begin{array}{l}- \\
17.1^{*} \\
(-2.9)\end{array}$ & $\begin{array}{l}68093 \\
* \\
(2.2)\end{array}$ & $\begin{array}{l}0.49 \\
6\end{array}$ \\
\hline Ochon & $\begin{array}{l}646348 \\
(2.624)\end{array}$ & $\begin{array}{l}1095 \\
27^{\star *} \\
(1.9)\end{array}$ & $\begin{array}{l}2455^{*} \\
(0.11)\end{array}$ & $\begin{array}{l}0.98^{*} \\
(-0.15)\end{array}$ & $\begin{array}{l}2126 \\
* \\
(0.9)\end{array}$ & $\begin{array}{l}- \\
4457 \\
6^{* *} \\
(2.9)\end{array}$ & $\begin{array}{l}1066 \\
5 \\
(2.2)\end{array}$ & $\begin{array}{l}- \\
2419 \\
96^{*} \\
(- \\
2.21)\end{array}$ & $\begin{array}{l}- \\
17.1^{*} \\
(-2.9)\end{array}$ & $\begin{array}{l}-3.4 \\
(-2.2)\end{array}$ & $\begin{array}{l}99899 \\
4 \\
(3.00)\end{array}$ & $\begin{array}{l}0.59 \\
2\end{array}$ \\
\hline
\end{tabular}

Source: Field survey, 2011

Note : $\quad \begin{array}{rl}* & * \mathrm{t}-\text { Values significant at } 5 \% \\ & * * \\ * & =\mathrm{t}-\text { values significant at } 10 \%\end{array}$

Figure in parenthesis are standard errors. Judging from the value of the $R^{2}$ in the analysis above for the three markets one can conclude that this model, that is, linear equation is a good one compared with all other functional forms. That is, the independent variables put together could explain about 50 percent of the systematic variation in the dependent variable for the three markets. The F-value for the markets are also significant at 5 percent indicating that there is a significant linear relationship between the independent variables taken together and the average monthly sales in Alesi, Ekukunela and Ochon markets.

The Durbin Watson (DW) statistics for testing for autocorrelation shows that none exist in the model implying that the three markets are free from any form of serial autocorrelation. From the table 9, sex is significance at 10 percent level in Alesi, Ekukunnela and Ochun markets. Education has positive influence on sales of mushrooms at 5 percent level of significance in the study markets. Marital status has negative influence on sales of mushrooms in the study markets. While age, has positive influence on sales of mushrooms in study markets. Low income for investment in mushroom business hindered sales of mushroom in study markets. 
Transportation cost and consumption are significant of 5 percent in all the markets. Transportation cost and consumption on the other hand affect sales negatively in the markets.

Lastly, experience of marketers is significant at 5 percent level of significance in Ekukunela and Ochon markets.

\section{CONCLUSION}

This study has shown that the marketing of edible mushroom in the studied markets was completely dominated by women (mostly illiterates). It was discovered that the profit margin for Alesi, Ekukunela and Ochon Markets were N60,000.00,N56,000.00 and N52,000.00 respectively.

Some of the problems identified include difficulty in buying and assembling the products and lack of government involvement in maintained of markets. There is need to improve market facilities such as stores/lockup stores and storage facilities for edible mushroom. Extension agents should train sellers on proper handling of edible mushroom to ensure product quality and good sanitary environment in order to ensure customers' safety and product quality. It was therefore recommended that farmers should form Mushroom Grower and Marketing Cooperative to enable them obtain loans from banks. Banks should provide loans with low interest rate to both small and large -scales mushroom farmers and marketers not politicians, motor park boys or civil servant. Furthermore, extension agents should monitor beneficiaries of such loans to ensure that farmers or marketers do not divert funds to buy motor-cycles, cars or marry more wives and also they should ensure regular repayment of loans by loan beneficiaries. The study also recommended that government should implement action -research type of programs that integrate institutional-technical and socioeconomic aspect of mushroom farming and include post harvest and marketing aspects either through cooperatives or export processing zones. Finally, the study recommended that serious attention should be paid to improve the markets to perfect markets for optimal efficiency.

\section{REFERENCES}

Akpet, S. O., Arikpo, G. E., Agbogo, E. A and Ogbonnaya, L. O., 2005. Indigenous Knowledge in Supplementing Dietary Protein needs Among The Rural Population of Cross River State. A Proceedings of the $2^{\text {nd }}$ annual Conference of the Nigeria Society of Indigenous Knowledge and Development held at Cross River University of Technology, Faculty of Agriculture and Forestry, Obubra, Cross River State, Nigeria, $19^{\text {th }}-12^{\text {th }}$ November, 2005. 1-5.

Cross River Agricultural Development, Report., 1992. 110.

Edith, L., 2004. Edible and Medicinal Mushroom Farming. In: MOFINEWS; Personal Communication, November, 2004. 1-9.
Ekpo, E. N., 2000. Description of some Edible Mushrooms in South-West Nigeria in Forestry Extension Bulletin Vol.1No 1.Published by Daybis, 10A Akinola Maja Avenue, Jericho, Ibadan .Email:daybis@skannet. Com. 1-12.

Ekpo, E. N., 2001. Guide to Edible Mushroom Cultivation in Forest Research Institute of Nigeria. Published by Daybis, 10A Akinola Maja Avenue, Jericho, Ibadan. Email:daybis@skannet.Com.1-8.

Ekpo, E. N., Daodu, O. O and Banjo, N. O., 2004. Effect of different substrates on Growth and Yield of Pleurotus Sajorcaju(EV) Singer. Journal of Forestry Research Management Not 1\&2, Forestry Research Institute of Nigeria, Ibadan, Nigeria.

FAO., 1974. Food and Agricultural Organization Production Year book Vol. 28 Rome, Italy. 3-9.

Grey, W. D., 1970. The Use of Fungi as Food in Processing, Butterworths, London, 113p.

Kennedy, E., 2004. Mushroom and Culture In: MOFINEW (2004).3, (6): 4-5.

Kohl's, J. L and Uhl, J. N., 1980. Marketing of Agricultural Products Macmillan Publishers, New York, 1 - 10.

MOFINEWS., 2004. Why Agriculture? Cross River State: Producing Milk and Honey for the Nation. A Bi- Monthly Journal of Finance incorporated, Calabar, Cross River State, Nigeria. July-August (2004) 3, (6): 4-5.

Nicholson, R. A., 1989. Common Mushrooms found in Akwa Ibom State. The Nigeria Field 54, 19 -32.

Oei, P., 1996. Mannual on Mushroom Cultivation, Leiden: Tool Publication. 24.

Ogbonnaya, L. O., 2006. Cultivation and Organoleptic Studies of three Edible Mushrooms in Nigeria. Ph.D thesis unpublished River State University of Science and Tech. Port -Harcourt, Nigeria.

Quarterly Newsletter of The Ministry of Local Government Affairs, Cross River State2006 4-8.

Quimio, T. R and Chang, S. T., 1990. Technical Guidelines for Mushroom Growing in the Tropic. FAO Plant Production paper (106): 155.

Ramsbottom, J., 1977. Mushrooms and Toadtools. A Study of the Activities of fungi. Collins London 306.

WWF., 1990. Medical Plants Conservation. WWF Reports August/September 1990. 
Tournefort, I., 1707. Mushroom Cultivation in France In: Quimio, T.R. and Chang S.T. (1990).Technical Guide lines for mushrooms growing in the Tropic FAO plant production No106, 155. 